\title{
Action of aldosterone upon the intestinal transport of potassium, sodium, and water ${ }^{1}$
}

\author{
R. SHIELDS ${ }^{2}$, ADELE T. MULHOLLAND ${ }^{3}$, AND R. G. ELMSLIE \\ From the Department of Surgery, The Western Infirmary, Glasgow, \\ and The Royal Infirmary, Cardiff
}

EDITORIAL SYNOPSIS There are interesting similarities between the handling of electrolytes by the intestine and by the renal tubules. These studies suggest that in states of increased adrenocortical activity, potassium losses into the intestinal lumen may be high, and go unrecognized clinically.

There is increasing evidence that the intestinal handling of electrolytes can be influenced by the secretions of the adrenal cortex. Early observations in rats (Clark, 1939) and in dogs (Dennis and Wood, 1940) showed that after adrenalectomy the absorption of sodium and chloride by the small intestine was reduced but in the rat could be restored to normal by the administration of 11-de-oxycorticosterone (D.O.C.) (Stein and Wertheimer, 1941). Subsequent experimental and clinical observations (Shields, 1964) have suggested that the adrenal mineralocorticoids enhance the absorption of sodium and the secretion of potassium by the intestine.

Water and electrolytes are, however, simultaneously exchanged in both directions across the intestinal mucosa (Visscher, Fetcher, Carr, Gregor, Bushey, and Barker, 1944a; Visscher, Varco, Carr, Dean, and Erickson, 1944b). Berger, Kanzaki, and Steele (1960) described the effects of D.O.C. upon this two-way traffic of electrolytes across the mucosa of the bowel of dogs. They found that the rate of net absorption of sodium by the colon was increased because of an increase in the rate at which sodium ions left the intestinal lumen and entered the body. The net secretion of potassium by the colon was enhanced by an increase in the rates of transport in both directions, movement into the colonic lumen being affected to a greater extent. 11-De-oxycorticosterone did not affect the movements of electrolytes in the small intestine.

11-De-oxycorticosterone, however, is probably

${ }^{1}$ A preliminary report of this work was given to the Surgical Research Society (Shields and Elmslie, 1962).

'Present address: The Surgical Unit, Royal Infirmary, Cardiff.

sPresent address: The Royal Infirmary, Stirling, Scotland.

'Present address: Department of Surgery, University of New South Wales, Sydney, Australia. not a natural salt-active product of the adrenal cortex (Kruhøffer, Thaysen, and Thorn, 1960). Aldosterone, the potency of which is 60 to 80 times that of D.O.C. (Tait, Simpson, and Grundy, 1952; Grundy, Simpson, and Tait, 1952), has been synthesized (Schmidlin, Anner, Billeter, and Wettstein, 1955) and is available commercially. It was therefore decided to study the effects of the more potent natural mineralocorticoid, aldosterone, upon the rates of transport of potassium, sodium, and water in isolated segments of ileum and colon of the dog and of colon in man.

\section{MATERIALS AND METHOD}

PREPARATION OF DOGS Five healthy female mongrels, weighing 8 to $15 \mathrm{~kg}$. and freed from intestinal parasites, were trained to lie quietly for periods of eight hours. In each animal, a Thiry-Vella fistula of ileum or of colon was fashioned by isolating a length of intestine without disturbing its blood supply and opening its ends on to the anterior abdominal wall as a Brooke type ileostomy (Fig. 1). Continuity of the intestinal tract was re-established by end-to-end anastomosis (Dennis, 1939).

In two dogs an ileal fistula, approximately $22 \mathrm{~cm}$. long, was prepared from bowel $10 \mathrm{~cm}$. cranial to the ileocaecal junction. In three dogs, a colonic fistula was fashioned from the cranial $16 \mathrm{~cm}$. of large b owel. These lengths of intestine provided a serosal surface area of $100 \mathrm{~cm}^{2}$. After three weeks, absorption tests were bəgun; all experiments were performed within six months of the construction of the fistula. The fistulas were rinsed at least three times each week with isotonic saline solution.

METHOD Each experiment consisted of a series of absorption tests, the first at 9.00 a.m. and the last about 5.00 p.m. All experiments were carried out at the same time of day to minimize any variation to diurnal rhythm in electrolyte transport. 


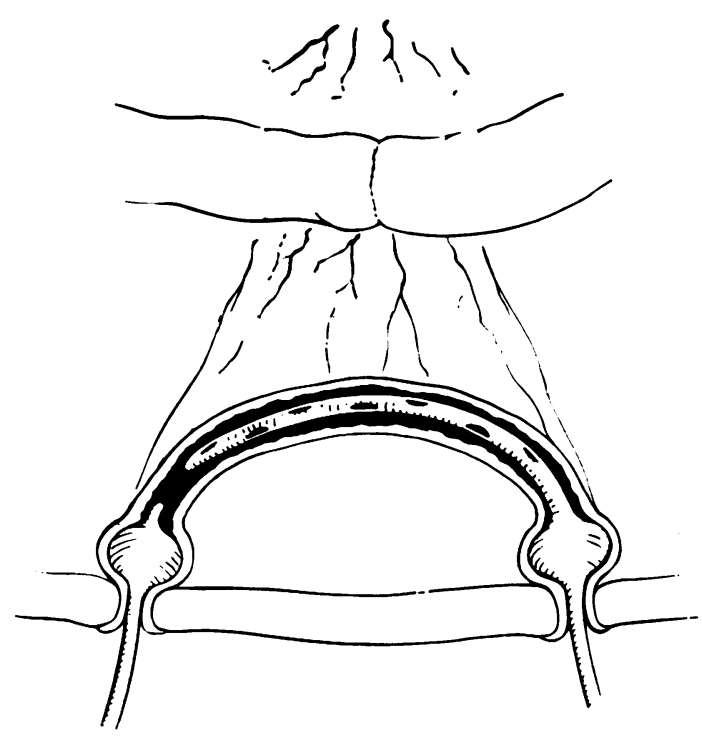

FIG. 1. Thiry-Vella fistula.

One end of the fistula is sealed by the balloon of Foley catheter. Into the other end is inserted a multiperforate tube carrying a balloon which, when inflated, prevents leakage of the intraluminal solution.

At the commencement of an experiment, the urinary bladder was emptied by a urethral catheter; thereafter urine was collected hourly.

During an experiment, solutions were instilled into and withdrawn from the isolated intestinal segments through a multi-perforate Foley catheter, modified by placing a balloon 16 or $22 \mathrm{~cm}$. from its tip (Code, Bass, McClary, Newnum, and Orvis, 1960). A second catheter was inserted into the other end of the fistula and the balloon on each catheter inflated (Fig. 1).

The Thiry-Vella fistula was irrigated with Tyrode's solution until the returning fluid was clear. Thirty minutes later, a series of 10-minute absorption tests was begun. At the end of the second test, an intravenous infusion of $5 \%(\mathrm{w} / \mathrm{v})$ dextrose was set up and continued at a rate of $40 \mathrm{ml}$. per hour. Absorption tests were performed at one, two, two and three-quarters, three and a half, four, and five hours after the beginning of the dextrose infusion.

Experiments performed in this way acted as controls, with which other experiments, in which aldosterone was given, were compared. Two control experiments were performed in each dog so that a total of 70 10-minute tests was carried out under control conditions.

TYPE OF EXPERIMENT Three types were performed, similar to the control experiments, except that aldosterone in aqueous solution (Aldocorten, Ciba) was administered:

1 Aldosterone infusion (high dose) After the second of the initial two tests, $250 \mu \mathrm{g}$. aldosterone was injected intravenously and a further $250 \mu \mathrm{g}$. was added to the dextrose solution and delivered to the dog at a rate of
$1 \mu \mathrm{g}$. per minute for the remainder of the experiment. Two such experiments were undertaken in each dog: 69 absorption tests were performed during the infusion of aldosterone in high dosage.

2 Aldosterone infusion (low dose) Aldosterone, added to the dextrose solution, was infused intravenously at a rate of $8 \mu \mathrm{g}$. per hour after the second of the initial two tests. No preliminary 'boosting' dose of aldosterone was given. One experiment of this type was performed upon each dog: 24 absorption tests were carried out during the infusion of aldosterone in low dosage.

3 Injection of aldosterone Five hundred $\mu \mathrm{g}$. aldosterone was injected directly into a vein, over a period of five minutes, after the dextrose infusion had been established. Only three experiments of this type were performed, two upon a dog with an ileal fistula, and one in a dog with a colonic fistula.

The type of experiment was randomly selected on each occasion.

PREPARATION IN MAN The intestinal transport of potassium and sodium was studied in two patients with the colon isolated for several weeks from the rest of the gastrointestinal tract. In each patient, a carcinoma of the midthird of the oesophagus had been resected and an isolated segment of transverse colon had been placed in the anterior mediastinum, in preparation for later anastomosis to the cervical oesophagus and to the stomach. Since both ends of the colon opened on to the skin surface, these patients possessed, in effect, a Thiry-Vella fistula.

Into each patient $250 \mu \mathrm{g}$. aldosterone was injected intravenously and a further $100 \mu \mathrm{g}$. aldosterone was added to a solution of $5 \%(w / v)$ dextrose which was infused intravenously to deliver $1 \mu \mathrm{g}$. aldosterone per minute. Two 10-minute absorption tests were performed at approximately 30 to 90 minutes from the beginning of the infusion of aldosterone.

Two control absorption tests were undertaken in each patient during the infusion of dextrose solution alone. These absorption tests were performed upon the patients in a manner similar to that upon the dogs.

\section{COMMON EXPERIMENTAL PROCEDURE}

ABSORPTION TESTS An absorption test was begun by instilling test solution ( $25 \mathrm{ml}$. in dogs, $50 \mathrm{ml}$. in man) into the fistula by means of a syringe which, throughout the test, was held in a clamp just above the isolated segment. During the test, fluid was allowed to rise and fall in the catheter, and at three and six minutes after the beginning of the test the solution was withdrawn and re-instilled to encourage intraluminal mixing. At 10 minutes as much as possible of the fluid within the intestine was aspirated. The volume of this aspirate was noted. The segment was immediately washed with $100 \mathrm{ml}$. non-radioactive Tyrode's solution and the volume of the rinse noted. The bowel was then allowed to drain freely for at least 30 minutes before the next test. Tests in which solution leaked from the isolated segment were abandoned.

TEST SOLUTION The test solution was freshly-prepared Tyrode's solution (Code and McIntire, 1956), containing 
the radioactive isotopes of potassium $\left({ }^{42} \mathrm{~K}, 4 \mu \mathrm{c}\right.$. per litre solution) and of sodium $\left({ }^{24} \mathrm{Na}, 2 \mu \mathrm{c}\right.$. per litre solution), and the stable isotope of water, deuterium oxide $\left(\mathrm{D}_{2} \mathrm{O}, 1 \%\right.$ $\mathrm{w} / \mathrm{v})$. The reaction of the test solution, measured by a glass electrode $p \mathrm{H}$ meter, was brought to $p \mathrm{H} 7$ with $0 \cdot 1 \mathrm{~N}$ hydrochloric acid. The test solution was kept in a stoppered flask and maintained at a temperature of $37^{\circ} \mathrm{C}$. in a water bath.

All solutions containing $\mathrm{D}_{2} \mathrm{O}$ were stored in firmlystoppered flasks, or, where possible, in sealed ampoules.

ESTIMATIONS The test solutions were estimated as follows:-

Potassium and sodium The concentrations of potassium and sodium in the test solution, and in the urine, were estimated by flame photometry.

Radioactive potassium and sodium The individual activities of radioactive potassium and sodium in the test solutions were determined by differential counting (Veall and Vetter, 1958) using a thick-walled liquid GeigerMuller M6 tube and a well-type scintillation counter with a thallium-activated sodium iodide crystal. Corrections were made for the 'dead-time' of the beta counter and for radioactive decay during the course of the experiment.

Deuterium oxide The concentrations of $\mathrm{D}_{2} \mathrm{O}$ in the test solution were determined by infra-red spectrophotometry using a modification of the method of BerglundLarsson (1956). The measurements were carried out in a Perkin-Elmer infra-red spectrometer, model 237. The home-made cells were constructed by cementing two quartz crystalline slides (Vickers Instruments, Limited, M8588) on either side of lead spacers, $0.08 \mathrm{~mm}$. thick. The exact thickness of a cell was determined by weighing it empty and then full of water. A calibration curve was prepared by plotting optical density at $2490 \mathrm{~cm} .^{-1}$ against atom percent $\mathrm{D}_{2} \mathrm{O}$ over the range 0.5 to $2 \%$ with an upper limit of $6 \%$. Ordinary distilled water was used as a reference standard. All measurements were made rapidly to minimize the exchange of water while the sample was in the cell.

TERMINOLOGY The terminology used to describe the direction in which movement of water and electrolytes was taking place is based on that proposed by Code (1960). Movement out of the bowel into the body is called 'insorption'; movement in the opposite direction is called 'exsorption'. The term 'absorption' is applied to the situation in which movement into the body (insorption) is more rapid than movement in the opposite direction (exsorption). When the rate of exsorption is greater than that of insorption, the term 'secretion' is used. The semantics of intestinal absorption have been considered elsewhere (Shields, 1964).

CAlculations From the radioactivity acquired by the rinse, which was not initially radioactive, the volume of test solution, which could not be aspirated at the end of a 10-minute test, was calculated.

The rate of insorption of potassium, sodium, and water was calculated from the disappearance rate of the appropriate isotope from the intestine, using the formulae derived by Visscher et al. (1944a and b). The rate of net transport of a substance was calculated from the change in the total amount of the substance (labelled and unlabelled) in the lumen of the bowel. A decrease in intestinal content indicated absorption, and an increase, secretion. The rate of exsorption was then derived by substitution in the equation.

Rate of net movement $=$ rate of insorption - rate of exsorption

A positive value for net movement indicated that absorption had occurred; a negative value, secretion.

The formulae for the calculation of the rates of transport are given in the Appendix.

At the end of the project the dogs were killed and the isolated intestinal segment removed. The segment was opened up longitudinally and pinned on cork under slight uniform tension. Its serosal surface area was measured. The calculated rates of transport were then expressed in terms of $100 \mathrm{~cm}^{2}$ serosal surface area.

In man the rates of movement were expressed in terms of the mean length of the isolated segments of colon, viz., $30 \mathrm{~cm}$.

ASSUMPTIONS AND ERRORS OF THE METHOD The assumptions inherent in the method and in the calculations were as follows:-

1 The intestine was assumed to be incapable of discriminating between the two isotopes of an element.

2 The rates of insorption of potassium, sodium, and water were calculated from the rates of disappearance of their tracer nuclides from the luminal solution. It was assumed that these isotopes, on leaving the intestinal lumen, entered the body and neither accumulated in the intestinal mucosa nor re-entered the intestinal lumen. Visscher et al. (1944a and b) have demonstrated that these assumptions are valid as far as the transport of water and sodium is concerned.

Accumulation of sodium and water within the intestine cell would seem to be negligible for both direct counting of the mucosa (Curran and Solomon, 1957) and estimation of the concentration of $\mathrm{D}_{2} \mathrm{O}$ in the mucosa (Visscher et al., 1944a) have shown retention of less than $5 \%$ of the insorbed sodium and water in the intestinal wall. In the present study, direct counting of bowel excised immediately after a series of eight 10-minute absorption tests, performed upon Thiry-Vella fistulas of dogs, did not reveal any significant accumulation of radioactive potassium or sodium in the intestinal mucosa or musculature.

It was also assumed that tracer material, which had left the intestinal lumen, would not re-enter the lumen to any great extent. The actual error produced by the re-entry of insorbed tracer was measured in the following way.

Eight 10-minute absorption tests were performed in the usual manner using a Thiry-Vella fistula of a dog. Then $25 \mathrm{ml}$. non-radioactive Tyrode's solution was instilled into the lumen and withdrawn after 10 minutes. The radioactivity acquired by this solution during 10 minutes in the intestinal lumen was then determined. Six experiments were performed in this way upon several dogs. The mean radio-activities in the solution, which was initially nonradioactive, were found to be 15 counts per second (c.p.s.) emitted by ${ }^{24} \mathrm{Na}$ and 10 c.p.s. by ${ }^{42} \mathrm{~K}$. These count rates 
represent, respectively, $0.6 \%$ and $0.4 \%$ of the mean activity in the bowel at the end of a 10-minute absorption test. Therefore, the errors due to the re-entry of the radioactive isotopes into the intestinal lumen were of little significance.

3 In the derivation of the formulae for calculating the rates of transport (see Appendix), certain assumptions have been made:

(a) The specific activities of the electrolytes and water decreased while the test solution lay in the intestinal lumen. This reduction was brought about by the entry of unlabelled material into the intestinal lumen because it is assumed (1) that labelled and unlabelled substances leave the intestinal lumen in the proportion that they bear to one another within the lumen (see (1) above) and (2) that negligible quantities of tracer material will re-enter the lumen (see (2) above).

In the calculation of the rates of insorption (equation 5 , Appendix) the mean specific activity of the test solution has been calculated from the arithmetic mean of the specific activities at the beginning and end of the test period. Although many workers have employed the arithmetic mean (Visscher et al., 1944b; Cooperstein and Brockman, 1959; Code et al., 1960; Grim, 1962), its use has been criticized by Berger and Steele (1958). However, these last authors pointed out that the difference between the mean specific activity, calculated using their formula, and that obtained from the arithmetic mean can be neglected if the change in specific activity during the test period is less than $40 \%$. This was achieved in the present study by restricting the test period to 10 minutes.

(b) Visscher's formulae do not allow for the fact that frequently the movement of water and electrolytes out of and into the bowel may be exponential in character. However, the form of the exponential curve (Code et al., 1960) is such that the rates of transport are linear with time until $50 \%$ of the isotope has been insorbed. Because less than $20 \%$ of the isotope is insorbed during a 10-minute test period the rates calculated from the Visscher formula and from an exponential equation should be similar. This similarity has been confirmed experimentally (Code et al., 1960).

4 The accuracy of the method is also dependent upon satisfactory discrimination between ${ }^{24} \mathrm{Na}$ and ${ }^{42} \mathrm{~K}$ in the test solutions. The technique used (Veall and Vetter, 1958) is based on the difference between the emissions of these isotopes. While both isotopes emit high energy beta radiations, ${ }^{24} \mathrm{Na}$ emits much more gamma radiation than ${ }^{42} \mathrm{~K}$. If a mixed sample is counted in a scintillation counter most of the observed counts will originate from ${ }^{24} \mathrm{Na}$, particularly when the discriminater is adjusted in favour of the higher energy gamma rays of this isotope. If the same sample is counted in a thick-walled beta counter the high energy beta rays of ${ }^{42} \mathrm{~K}$ are only slightly affected but the transmission of the beta particles from ${ }^{24} \mathrm{Na}$ is substantially reduced. This method of discrimination will be valid only if samples are counted in both types of counter simultaneously because correction for radioactive decay cannot be applied to the mixtures owing to the differences in the half-lives of the two isotopes.

The errors in deriving the separate activities by this technique were calculated according to the formulae of
Robinson, Arons, and Solomon (1955). The error in deriving ${ }^{24} \mathrm{Na}$ activity was found to be $3 \%$ because of the tendency of the gamma counter to count the gamma emissions of ${ }^{42} \mathrm{~K}$. The error in deriving ${ }^{42} \mathrm{~K}$ activity in a mixture was $1 \%$.

5 The errors in estimating sodium and potassium by flame photometry were found to be $1.3 \%$ and $2.5 \%$ respectively.

6 The error in estimating deuterium oxide by infra-red spectrophotometry was calculated to be $0.86 \%$.

The total error of the method is probably not less than $10 \%$.

\section{RESULTS IN THE DOG}

\section{INFUSION OF ALDOSTERONE (HIGH DOSE)}

1 Rates of transport of potassium, sodium, and water The effect of a continuous intravenous infusion of aldosterone upon the intestine is best appreciated by regarding the results of a single experiment. In the

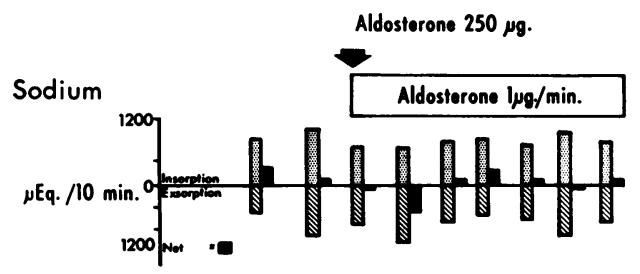

Potassium
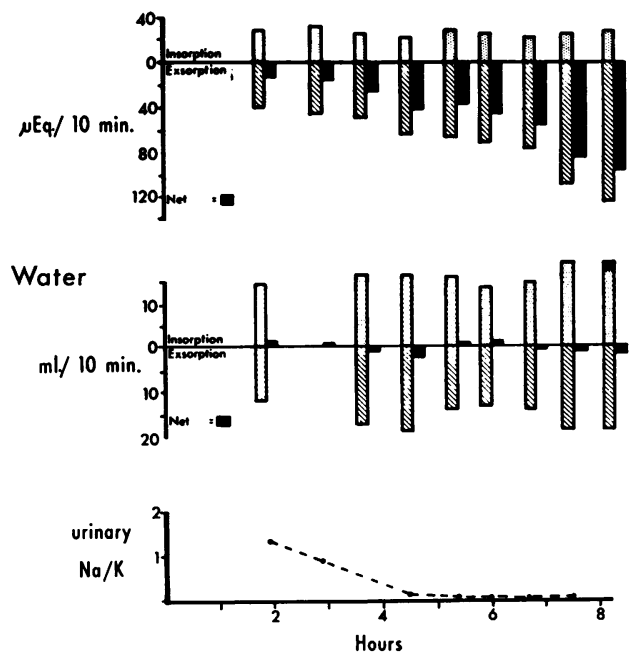

FIG. 2. The effect of a continuous infusion of aldosterone upon the transport of sodium, potassium, and water in a Thiry-Vella fistula of ileum of a dog.

The rates of insorption (stippled block) are charted above, and those of exsorption (hatched block) below the horizontal line. Net movement (solid block) is charted se that the height of the block above the line represents tho rate of absorption, and the depth below the line, rate of secretion. 


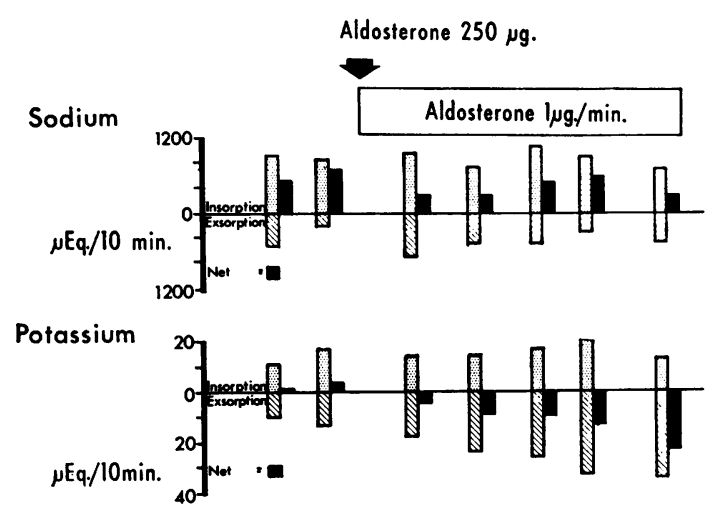

Water

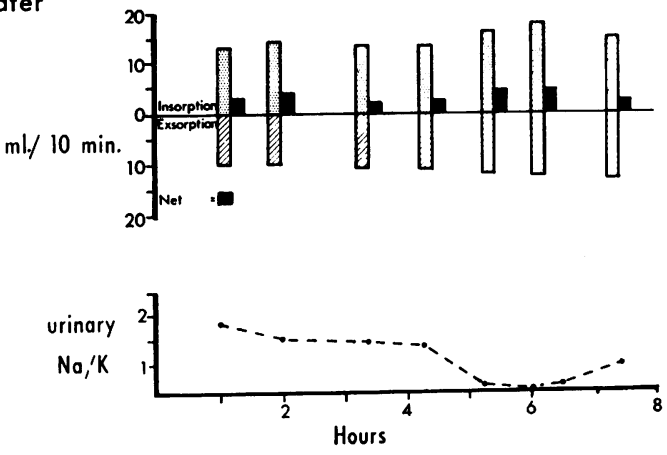

FIG. 3. The effect of a continuous infusion of aldosterone upon the transport of sodium, potassium, and water in a Thiry-Vella fistula of colon of dog.

The conventions used for charting directions and rate of movement are identical to those of Figure 2. ileum (Fig. 2) and colon (Fig. 3) the most obvious effect was an increase in the rate at which potassium ions entered the lumen (exsorption); this effect became most marked four and five hours after the beginning of the aldosterone infusion. Since the rate of potassium movement in the opposite direction (insorption) was unaltered, the net result was an increase in the rate of potassium secretion. In the ileum, secretion was increased seven-fold; in the colon the slight net absorption of potassium, which was observed initially, was converted into secretion, ultimately at a rate of $23 \mu \mathrm{Eq}$. per 10 minutes, five hours after the beginning of the aldosterone infusion. The experiments were usually terminated after five hours of continuous infusion because the dogs became restless. The altered rates of potassium transport had returned to normal on the following day.

To allow statistical evaluation of the action of aldosterone, the rates of intestinal transport in dogs receiving aldosterone were compared with the rates in the same dog, at similar times, in control experiments. The effect of aldosterone was taken as the difference between the rates of transport with aldosterone and those without. From these results the mean difference and its standard error were calculated, along with the probability that it differed from zero. In Tables I and II are shown the changes in the rates of movement when aldosterone had been infused for four and five hours, for at these times the effects of aldosterone were most pronounced. In the ileum (Table I) aldosterone produced an increased secretion of potassium, entirely due to an increased rate of entry of the ion into the lumen; movement of potassium in the opposite direction was unaltered. The transport rates of sodium and of water were un-

TABLE I

MEAN RATES OF TRANSPORT IN THE ILEUM OF CONTROL DOGS FOUR AND FIVE HOURS AFTER BEGINNING OF DEXTROSE INFUSION AND DIFFERENCE IN RATES AFTER ALDOSTERONE

\begin{tabular}{|c|c|c|c|c|c|c|c|}
\hline Substance & $\begin{array}{l}\text { Direction of } \\
\text { Movement }\end{array}$ & $\begin{array}{l}\text { Mean Rate } \\
\text { in Controls } \\
\text { at } 4 \text { Hours } \\
\text { (a) }\end{array}$ & $\begin{array}{l}\text { Mean Difference } \\
\text { with Aldosterone } \\
\pm \text { S.E.M. } \\
\text { Difference (b) }\end{array}$ & $P(c)$ & $\begin{array}{l}\text { Mean Rate } \\
\text { in Controls } \\
\text { at } 5 \text { Hours } \\
\text { (a) }\end{array}$ & $\begin{array}{l}\text { Mean Difference } \\
\text { with Aldosterone } \\
\pm \text { S.E.M. } \\
\text { Difference (b) }\end{array}$ & $P(c)$ \\
\hline $\begin{array}{l}\text { Sodium } \\
(\mu \text { Eq. } / 10 \mathrm{~min} .)\end{array}$ & $\begin{array}{l}\text { Insorption } \\
\text { Exsorption } \\
\text { Net }\end{array}$ & $\begin{array}{c}294(3)^{1} \\
824(3) \\
-530(3)\end{array}$ & $\begin{array}{r}+95 \pm 48(6) \\
-20 \pm 76(6) \\
+196 \pm 126(6)\end{array}$ & $\begin{array}{l}>0.1 \\
>0.9 \\
>0.2\end{array}$ & $\begin{array}{r}358(3) \\
837(3) \\
-479(3)\end{array}$ & $\begin{array}{r}+88 \pm 54(6) \\
-152 \pm 78(6) \\
+122 \pm 110(6)\end{array}$ & $\begin{array}{l}>0.2 \\
>0.2 \\
>0.4\end{array}$ \\
\hline $\begin{array}{l}\text { Potassium } \\
\text { ( } \mu \text { Eq. } / 10 \mathrm{~min} .)\end{array}$ & $\begin{array}{l}\text { Insorption } \\
\text { Exsorption } \\
\text { Net }\end{array}$ & $\begin{array}{r}14(3) \\
42(3) \\
-28(3)\end{array}$ & $\begin{array}{r}+2 \pm 3(6) \\
+31 \pm 10(6) \\
-31 \pm 9(6)\end{array}$ & $\begin{array}{l}>0.4 \\
<0.05 \\
<0.05\end{array}$ & $\begin{array}{r}18(3) \\
40(3) \\
-22(3)\end{array}$ & $\begin{array}{rr}-3 \pm & 3(6) \\
+41 \pm 11(6) \\
-44 \pm 24(6)\end{array}$ & $\begin{array}{l}>0.4 \\
<0.02 \\
<0.01\end{array}$ \\
\hline Water $(\mathrm{ml} . / 10 \mathrm{~min}$. & $\begin{array}{l}\text { Insorption } \\
\text { Exsorption } \\
\text { Net }\end{array}$ & $\begin{array}{r}10 \cdot 3(2) \\
13 \cdot 4(2) \\
-2 \cdot 7(4)\end{array}$ & $\begin{array}{l}+0.8 \pm 1.9(5) \\
+0.9 \pm 1.9(5) \\
+1.3 \pm 0.6(6)\end{array}$ & $\begin{array}{l}>0.7 \\
>0.7 \\
>0.1\end{array}$ & $\begin{array}{r}12.5(2) \\
14.9(2) \\
-2.3(4)\end{array}$ & $\begin{array}{l}-0.5 \pm 1.9(4) \\
-0.6 \pm 2.2(4) \\
+0.5 \pm 0.6(6)\end{array}$ & $\begin{array}{l}>0.7 \\
>0.8 \\
>0.5\end{array}$ \\
\hline
\end{tabular}

${ }^{1}$ The figures in parentheses indicate the number of tests performed.

Notes: (a) In this column the minus sign before mean rate indicates secretion.

(b) In this column the plus sign indicates increase above, and minus sign decrease below, mean rate in control experiments.

(c) $\mathbf{P}$ represents the probability that the mean difference in rates of movement is zero. 


\section{TABLE II}

MEAN RATES OF TRANSPORT IN THE COLON OF CONTROL DOGS FOUR AND FIVE HOURS AFTER BEGINNING OF DEXTROSE INFUSION AND DIFFERENCE IN RATES AFTER ALDOSTERONE

\begin{tabular}{|c|c|c|c|c|c|c|c|}
\hline Substance & $\begin{array}{l}\text { Direction of } \\
\text { Movement }\end{array}$ & $\begin{array}{l}\text { Mean Rate } \\
\text { in Controls } \\
\text { at } 4 \text { Hours }\end{array}$ & $\begin{array}{l}\text { Mean Difference } \\
\text { with Aldosterone } \\
\pm \text { S.E.M. } \\
\text { Difference }\end{array}$ & $\boldsymbol{P}$ & $\begin{array}{l}\text { Mean Rate } \\
\text { in Controls } \\
\text { at } 5 \text { Hours }\end{array}$ & $\begin{array}{l}\text { Mean Difference } \\
\text { with Aldosterone } \\
\pm \text { S.E.M. } \\
\text { Difference }\end{array}$ & $\boldsymbol{P}$ \\
\hline $\begin{array}{l}\text { Sodium } \\
(\mu \mathrm{Eq} . / 10 \mathrm{~min} .)\end{array}$ & $\begin{array}{l}\text { Insorption } \\
\text { Exsorption } \\
\text { Net }\end{array}$ & $\begin{array}{c}520(5)^{1} \\
368(5) \\
+152(5)\end{array}$ & $\begin{array}{l}+20 \pm 125(5) \\
-47 \pm 106(5) \\
+69 \pm 94(5)\end{array}$ & $\begin{array}{l}>0.9 \\
>0.7 \\
>0.6\end{array}$ & $\begin{array}{r}577(4) \\
382(4) \\
+195(4)\end{array}$ & $\begin{array}{l}+30 \pm 128(5) \\
-18 \pm 67(5) \\
+48 \pm 146(5)\end{array}$ & $\begin{array}{l}>0.9 \\
>0.8 \\
>08\end{array}$ \\
\hline $\begin{array}{l}\text { Potassium } \\
(\mu \mathrm{Eq} . / 10 \mathrm{~min} .)\end{array}$ & $\begin{array}{l}\text { Insorption } \\
\text { Exsorption } \\
\text { Net }\end{array}$ & $\begin{array}{r}14(4) \\
27(4) \\
-13(4)\end{array}$ & $\begin{array}{r}-2 \pm 3(5) \\
+29 \pm 16(5) \\
-31 \pm 18(5)\end{array}$ & $\begin{array}{l}>0.6 \\
>0.1 \\
>0.1\end{array}$ & $\begin{array}{r}14(3) \\
27(3) \\
-13(3)\end{array}$ & $\begin{array}{r}-4 \pm \quad 3(5) \\
+43 \pm 16(5) \\
-47 \pm 16(5)\end{array}$ & $\begin{array}{l}>0.3 \\
<0.05 \\
<0.05\end{array}$ \\
\hline Water (ml./10 min.) & $\begin{array}{l}\text { Insorption } \\
\text { Exsorption } \\
\text { Net }\end{array}$ & $\begin{array}{r}13.1(4) \\
11.9(4) \\
+1.1(5)\end{array}$ & $\begin{array}{l}-1.1 \pm 1.8(4) \\
-0.2 \pm 1.5(4) \\
+0.2 \pm 1.1(5)\end{array}$ & $\begin{array}{l}>0.6 \\
>0.9 \\
>0.9\end{array}$ & $\begin{array}{r}13.0(3) \\
12.3(3) \\
+0.8(4)\end{array}$ & $\begin{array}{l}+0.1 \pm 1.3(4) \\
-0.6 \pm 0.8(4) \\
+0.7 \pm 0.9(5)\end{array}$ & $\begin{array}{l}>0.9 \\
>0.5 \\
>0.5\end{array}$ \\
\hline
\end{tabular}

The figures in parentheses indicate the number of tests performed.

See footnotes of Table I.

altered during the infusion of aldosterone. Under control conditions, potassium, sodium, and water were secreted into the ileum.

In the colon (Table II) the action of aldosterone was similar but less pronounced. The rates of exsorption and secretion of potassium were increased after four and five hours of infusion of aldosterone; these increases became significant after five hours. The rate of potassium insorption and the rates of transport of sodium and water were not affected.

Concentration of electrolyte in the intestinal lumen In both the ileum and the colon the concentrations of potassium in the test solution increased during the 10-minute absorption tests (Table III). In control experiments, the rise in potassium concentration, although significant, was not great, $0.5 \mathrm{mEq}$. per litre in the ileum and $0.6 \mathrm{mEq}$. per litre in the colon. After the administration of aldosterone the increase in the concentration of potassium in the luminal solution was much greater, $2.19 \mathrm{mEq}$. per litre in the ileum and $2.29 \mathrm{mEq}$. per litre in the colon. This increase in the concentration of potassium in the lumen after four hours of aldosterone infusion was significantly greater $(P<0.001)$ than the much smaller rise observed at a corresponding time in control experiments.

The concentration of sodium in the test solution did not change appreciably during 10 minutes in the lumen of the ileum or colon whether aldosterone had or had not been given (Table IV).

3 Relationship between potassium and sodium movement No correlation could be obtained between potassium and sodium transport to define any ion-for-ion exchange across the intestinal mucosa.

4 Urinary concentrations of potassium and sodium The pattern of urinary electrolyte excretion changed during the administration of aldosterone. The ratio of sodium: potassium in the urine was invariably decreased, while, in control experiments, the ratio fell only slightly, remained constant, or, more frequently, rose during the course of an experiment (Fig. 4).

INFUSION OF ALDOSTERONE (LOW DOSE) When

TABLE III

CONCENTRATION OF POTASSIUM IN INTESTINAL LUMEN AT BEGINNING $\left(t_{0}\right)$ AND END $\left(t_{10}\right)$ of 10-MINUTE ABSORPTION TESTS ${ }^{1}$

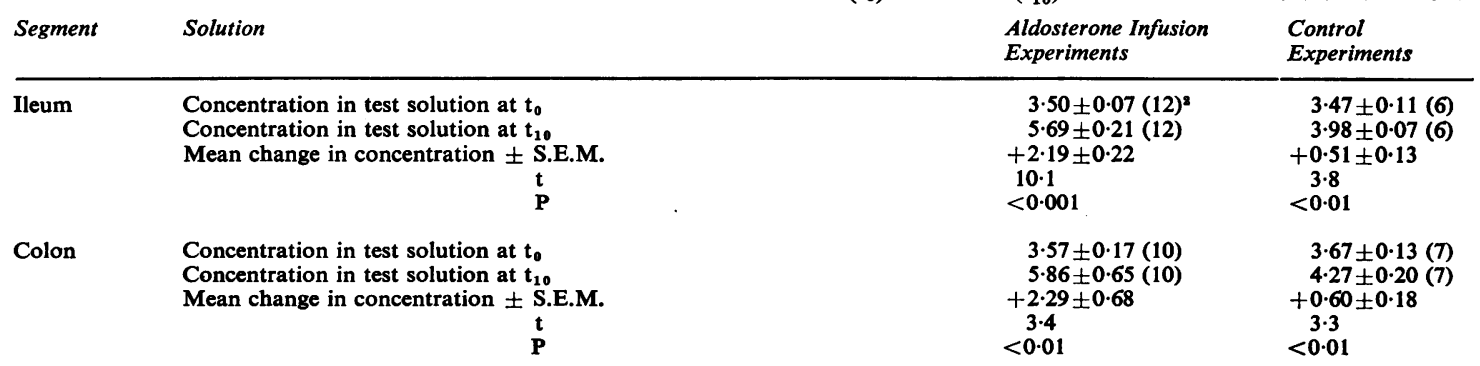

${ }^{1}$ The concentrations (mEq./1. \pm S.E.M.) were measured in tests performed four and five hours after the beginning of the dextrose infusion, with and without the administration of aldosterone.

Figures in parentheses indicate number of tests. 
TABLE IV

CONCENTRATION OF SODIUM IN INTESTINAL LUMEN AT BEGINNING $\left(t_{0}\right)$ AND END $\left(t_{10}\right)$ OF 10-MINUTE ABSORPTION TESTS ${ }^{1}$

\begin{tabular}{|c|c|c|c|}
\hline Segment & Solution & $\begin{array}{l}\text { Aldosterone Infusion } \\
\text { Experiments }\end{array}$ & $\begin{array}{l}\text { Control } \\
\text { Experiments }\end{array}$ \\
\hline Ileum & 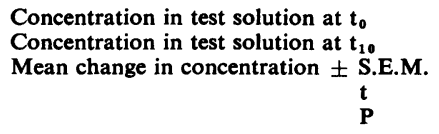 & $\begin{array}{l}149 \pm 3.8(12)^{2} \\
146 \pm 2.9(12) \\
-3.0 \pm 4.8 \\
0.59 \\
>0.5\end{array}$ & $\begin{array}{l}149 \pm 1 \cdot 1(6) \\
151 \pm 1 \cdot 3(6) \\
+2 \cdot 0 \pm 1 \cdot 7 \\
\quad 1 \cdot 39 \\
>0 \cdot 2\end{array}$ \\
\hline Colon & $\begin{array}{l}\text { Concentration in test solution at } t_{0} \\
\text { Concentration in test solution at } t_{10} \\
\text { Mean change in concentration } \pm \text { S.E.M. } \\
\qquad \\
\mathbf{P}\end{array}$ & $\begin{array}{l}147 \pm 1 \cdot 9(10) \\
145 \pm 2 \cdot 8(10) \\
-2 \cdot 0 \pm 3 \cdot 5 \\
0 \cdot 59 \\
>0 \cdot 5\end{array}$ & $\begin{array}{l}153 \pm 1 \cdot 65(7) \\
152 \pm 2 \cdot 1(7) \\
-1 \cdot 0 \pm 2 \cdot 7 \\
0.37 \\
>0.7\end{array}$ \\
\hline
\end{tabular}

${ }^{1}$ The concentrations (mEq./l. \pm S.E.M.) were measured in tests performed four and five hours after the beginning of the dextrose infusion, with and without the administration of aldosterone.

${ }^{2}$ Figures in parentheses indicate number of tests.

aldosterone was infused intravenously at a rate of $8 \mu \mathrm{g}$. per hour, the changes in potassium transport in both the ileum and the colon were similar to those observed during the infusion of the higher dose. Potassium secretion increased three-fold after four hours, becuase of an increase in the rate of potassium exsorption. The rate at which potassium ions left the intestinal lumen and entered the body was unaltered. The increase in potassium exsorption following the infusion of this lower dose of aldosterone was similar in magnitude to that observed with the higher dose (Table V). The rates of water and sodium transport in both parts of the bowel were unaffected by the administration of aldosterone in this low dose.

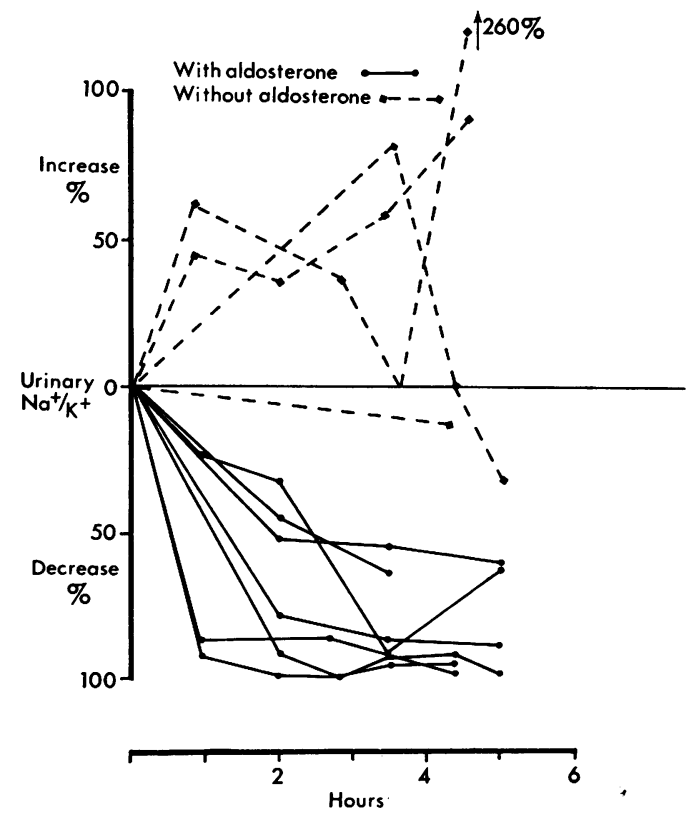

FIG. 4. The effect upon the urinary sodium: potassium ratio of a continuous intravenous infusion of aldosterone into dogs.

\section{TABLE V}

MEAN RATES OF POTASSIUM TRANSPORT UNDER CONTROL CONDITIONS AND MEAN DIFFERENCE AFTER ALDOSTERONE IN HIGH AND LOW DOSAGE ( \pm S.E. OF DIFFERENCE; P, PROBABILITY THAT THE DIFFERENCE IS ZERO)

\begin{tabular}{llll} 
& Insorption & Exsorption & Net \\
\hline $\begin{array}{l}\text { Control experiments } \\
(\mu \text { Eq./10 min.) }\end{array}$ & 15 & 33 & $-18^{1}$ \\
$\begin{array}{l}\text { Difference after high } \\
\text { dose of aldosterone }\end{array}$ & $\begin{array}{l}-1.5 \pm 1.3 \\
\text { P }\end{array}$ & $\begin{array}{l}+37.7 \pm 6.4 \\
<0.01\end{array}$ & $\begin{array}{l}-38.9 \pm 6.7 \\
<0.001\end{array}$ \\
$\begin{array}{l}\text { Difference after low } \\
\text { dose of aldosterone }\end{array}$ & $-0.3 \pm 2.3$ & $+37.6 \pm 8.3$ & $-37.9 \pm 9.8$ \\
$P$ & $>0.7$ & $<0.01$ & $<0.01$
\end{tabular}

${ }^{1}$ The minus sign preceding the mean rate of potassium movement indicates secretion.

${ }^{2}$ The plus and minus signs preceding the mean differences indicate increase above, or decrease below, the mean rates in control experiments.

The rates of transport in ileum and colon have been combined since the actions of aldosterone in both parts of the intestine are identical. In this analysis the rates of transport, four and five hours after the beginning of the dextrose infusion, have been compared.

SINGLE INJECTION OF ALDOSTERONE Following the injection of $500 \mu \mathrm{g}$. aldosterone, the rates of movement of sodium and water into and out of the intestine were not altered. Any alteration in potassium transport was transient and inconstant (Fig. 5).

\section{RESULTS IN MAN}

The isolated segments of human transverse colon in vivo absorbed sodium and secreted potassium ions (Table VI). In addition, water was absorbed. When aldosterone was infused intravenously the rates of transport of sodium ions into and out of the colonic lumen did not alter. However, following the administration of aldosterone, potassium ions entered the colonic lumen more rapidly. Because potassium transport in the opposite direction was unaffected, the net secretion of potassium was enhanced. Increase in the rate of potassium exsorption was 


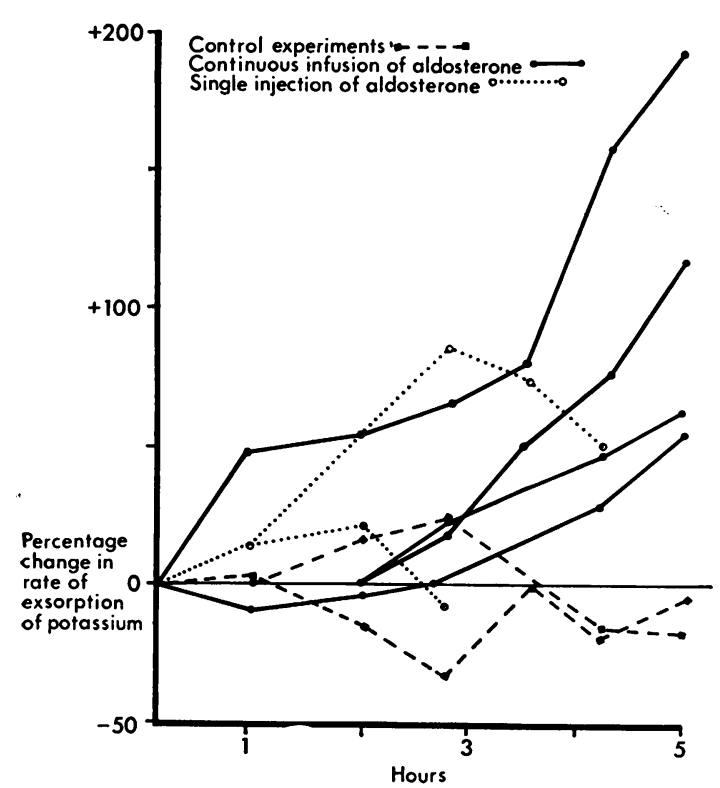

FIG. 5. The effect upon the rate of potassium exsorption, into a Thiry-Vella fistula of canine ileum, of a single injection of aldosterone compared with that of a continuous infusion of aldosterone. significant $(P<0.05) 30$ minutes after the infusion of aldosterone and highly significant $(\mathrm{P}<0.001)$ after 90 minutes.

In the control experiments potassium ions accumulated in the colonic lumen during the 10-minute test period (Table VII). A much greater rise in the luminal concentration of potassium was observed when aldosterone was infused, and the increase under these conditions was significantly greater $(t=4 \cdot 7$; $P<0.01)$ than the smaller rise observed in the control experiments.

In man the latent period before the action of aldosterone became manifest was much shorter than that in the dog.

\section{DISCUSSION}

Adrenocortical hormones are known to influence extrarenal tissues in a manner qualitatively similar to their striking effect upon the kidney. In sweat (Conn, Louis, Johnston, and Johnson, 1948; Conn, 1949) and in saliva (Frawley and Thorn, 1951) the ratio of sodium to potassium is reduced, and occasionally reversed, with increased activity of the adrenal cortex. In a similar way, the electrolyte composition of the intestinal content can be altered by the salt-active adrenal hormones (Shields, 1964).

TABLE VI

EFFECT OF ALDOSTERONE UPON MEAN RATES OF TRANSPORT OF SODIUM AND POTASSIUM ACROSS THE MUCOSA OF ISOLATED HUMAN COLON in vivo OF TWO PATIENTS (MEQ. PER 30 CM. LENGTH PER 10 MINUTES \pm S.E. OF MEAN)

\begin{tabular}{|c|c|c|c|c|c|}
\hline Ion & $\begin{array}{l}\text { Direction of } \\
\text { Movement }\end{array}$ & $\begin{array}{l}\text { Aldosterone } \\
\text { Experiment }^{2}\end{array}$ & $\begin{array}{l}\text { Control } \\
\text { Experiment }^{3}\end{array}$ & $\begin{array}{l}\text { Mean Difference } \\
\pm \text { S.E. Mean }\end{array}$ & $P$ \\
\hline Sodium & $\begin{array}{l}\text { Insorption } \\
\text { Exsorption } \\
\text { Net }^{1}\end{array}$ & $\begin{array}{r}1.42 \pm 0.06 \\
0.92 \pm 0.15 \\
+0.50 \pm 0.21\end{array}$ & $\begin{array}{r}1.32 \pm 0.11 \\
0.40 \pm 0.11 \\
+0.92 \pm 0.03\end{array}$ & $\begin{array}{l}0 \cdot 10 \pm 0.12 \\
0.52 \pm 0.36 \\
0.42 \pm 0.21\end{array}$ & $\begin{array}{l}>0.4 \\
>0.1 \\
>0.05\end{array}$ \\
\hline Potassium & $\begin{array}{l}\text { Insorption } \\
\text { Exsorption } \\
\text { Net }^{1}\end{array}$ & $\begin{array}{r}0.014 \pm 0.007 \\
0.599 \pm 0.058 \\
-0.585 \pm 0.056\end{array}$ & $\begin{array}{r}0.027 \pm 0.003 \\
0.376 \pm 0.041 \\
-0.349 \pm 0.040\end{array}$ & $\begin{array}{l}0.013 \pm 0.008 \\
0.223 \pm 0.070 \\
0.236 \pm 0.069\end{array}$ & $\begin{array}{l}>0.1 \\
<0.02 \\
<0.02\end{array}$ \\
\hline
\end{tabular}

${ }^{1}$ The plus and minus signs preceding the mean rates of net movement indicate absorption and secretion respectively.

${ }^{2}$ The rates of transport measured at 30 and 90 minutes after the beginning of the aldosterone infusion have been combined.

${ }^{3}$ Two control tests were performed in each patient.

\section{TABLE VII}

CONCENTRATION OF SODIUM AND POTASSIUM (MEQ./L \pm S.E.M.) IN LUMEN OF ISOLATED HUMAN COLON AT BEGINNING ( $t_{0}$ ) AND END $\left(\mathrm{t}_{10}\right)$ OF 10-MINUTE ABSORPTION TESTS DURING THE INFUSION OF ALDOSTERONE AND UNDER CONTROL CONDITIONS

\begin{tabular}{|c|c|c|c|}
\hline Ion & Solution & $\begin{array}{l}\text { Aldosterone } \\
\text { Experiment }\end{array}$ & $\begin{array}{l}\text { Control } \\
\text { Experiment }\end{array}$ \\
\hline Sodium & $\begin{array}{l}\text { Concentration at } t_{0} \\
\text { Concentration at } t_{10} \\
\text { Mean change in concentration } \pm \text { S.E.M. } \\
P\end{array}$ & $\begin{array}{l}148 \pm 0 \cdot 6 \\
148 \pm 1 \cdot 2 \\
0 \\
\text { N.S. }\end{array}$ & $\begin{array}{l}148 \pm 0 \cdot 6 \\
148 \pm 1 \cdot 7 \\
0 \\
\text { N.S. }\end{array}$ \\
\hline Potassium & $\begin{array}{l}\text { Concentration at } t_{0} \\
\text { Concentration at } t_{10} \\
\text { Mean change in concentration } \pm \text { S.E.M. } \\
P\end{array}$ & $\begin{aligned} & 3.95 \pm 0.09 \\
& 5.88 \pm 0.10 \\
&+1.93 \pm 0.134 \\
&<0.001\end{aligned}$ & $\begin{aligned} & 3.95 \pm 0.09 \\
& 4.73 \pm 0.22 \\
&+0.78 \pm 0.24 \\
&<0.02\end{aligned}$ \\
\hline
\end{tabular}


However, alterations in the ionic composition of the intestinal contents are brought about by changes in the rates at which electrolytes enter or leave the intestinal lumen. The present study confirms the work of Berger et al. (1960) that the bidirectional transport of electrolytes can be influenced by the adrenal mineralocorticoids. In several respects, however, the present findings differed from their observations.

First, the small intestine seemed to be responsive to aldosterone. Berger et al. (1960) did not observe any alteration in transport in the small intestine after D.O.C. Indirect evidence from the literature (Shields, 1964) suggests that the small intestine can indeed be influenced by the secretions of the adrenal cortex.

Secondly, in the present study, sodium transport was not appreciably affected by the administration of aldosterone. The reason for this remains obscure. It may be that the variability in the rates of sodium transport, encountered by most workers in this field (Visscher et al., $1944 \mathrm{a}$ and b; Bucher, Anderson, and Robinson, 1950; Curran and Solomon, 1957; Berger, Ranzaki, Homer, and Steele, 1959; Shields, 1965a), obscured any change in the intestinal handling of sodium produced by aldosterone. Another reason may be that just as the effect of mineralocorticoids on the renal excretion of sodium is difficult to demonstrate in acute experiments in a normal dog (Barger, Berlin, and Tulenko, 1958), so also is their action upon the bowel. Thus Barger and his colleagues showed that the infusion of aldosterone into the renal artery of intact dogs increased the secretion of potassium by the associated kidney but the excretion of sodium was unaffected. When the adrenal glands were removed, however, the kidney of the same dog exhibited not only potassium secretion, but also sodium retention with the same dose of aldosterone. These workers also noticed that the effects of aldosterone on the urinary excretion of sodium and of potassium did not coincide, and suggested that the effect of the mineralocorticoids upon potassium transport by the renal tubules was a primary one and not secondary to sodium transport. Certainly there is no evidence from the present work that the effect of mineralocorticoids upon potassium movement in the gut is anything but primary.

The close similarity between the renal and intestinal actions of aldosterone is striking. First at least 30 to 240 minutes elapsed after the injection of aldosterone before any alteration in the rate of electrolyte transport could be appreciated. A similar delay in the effect of aldosterone upon the renal excretion of electrolytes has been described in the dog (Barger $e t$ al., 1958) and in man (Dingman, Finkenstaedt, Laidlaw, Renold, Jenkins, Merrill, and Thorn, 1958). Second, the action of aldosterone upon the intestinal transport of electrolytes can be inhibited by spironolactones (Elmslie, Mulholland, and Shields, 1966), which also act upon the kidney as competitive blockers (Bartter, 1960). Third, the marked alterations in urinary electrolyte excretion which follow sodium depletion are accompanied by identical changes in the intestinal handling of electrolytes (Clarke and Shields, 1963).

A single intravenous injection of aldosterone did not produce any definite or constant change in electrolyte transport in the bowel. This finding can be attributed to the short life of aldosterone in the body (Ayers, Davis, Lieberman, Carpenter, and Berman, 1962), and the delay after administration before its effect is manifest. The most satisfactory technique was the one in which aldosterone was given by continuous intravenous infusion. The delay in producing a response in the gut cannot be ascribed to the time required to build up an effective concentration of aldosterone in the body, for delay occurred even after an initial booster dose of the mineralocorticoid had been given.

An infusion rate of $8 \mu \mathrm{g}$. per hour (low dose) is probably greater than the basal rate of secretion in the dog. No accurate figures are available. In the sheep, the basal secretion of aldosterone amounts to $0.48 \mu \mathrm{g}$. per hour; during sodium depletion, the rate of secretion is increased to $15 \mu \mathrm{g}$. per hour when changes in the electrolyte composition of saliva become apparent (Wright, 1962). On the basis of weight, a rate of $8 \mu \mathrm{g}$. per hour was selected as the rate at which, in the dog, aldosterone might be secreted if the adrenal cortex were stimulated, and at which an effect on extrarenal tissues, such as the gut, might probably be detected. Although the rate of $1 \mu \mathrm{g}$. per minute (high dose) is probably greater than that found under physiological conditions, such a rate of infusion has been used by many workers in the past. Certainly it is no more potent than the slower rate of infusion.

Within the framework of these experiments, the significance of the intestinal action of aldosterone in maintaining homeostasis must be assessed. Caution must be exercised in generalizing uncritically upon the action of steroids from a single type of experiment, in this case acute (Lipsett, Schwartz, and Thorn, 1961). In these studies in the dog and in man, sodium transport in the gut was not affected by aldosterone, perhaps for the reasons already given above. Most evidence from the literature (Shields, 1964), however, suggests that the absorption of sodium is enhanced by the adrenal mineralocorticoids. However, under normal conditions, the amount of sodium in the faeces is so small that a reduction in the faecal excretion of sodium in states of adrenal-cortical activity will contribute only slightly to the mainten- 
ance of homeostasis. However, the increased intestinal secretion of potassium under the influence of the mineralocorticoids can be of clinical importance. The daily faecal excretion of potassium, which represents $20 \%$ of the total loss of potassium by all routes, can be increased several-fold so that the extent of potassium deficiency may go undetected if only the urinary losses are measured. Thus, in a patient with primary hyperaldosteronism, the daily faecal losses of potassium were frequently observed to be more than half the urinary losses. In this patient, who had an aldosterone-producing tumour of the adrenal cortex, the increased faecal losses of potassium were brought about by an increase in the rate of transfer of potassium ions into the colonic lumen (Miles and Shields, 1966). In addition, failure to take into account the increased losses of potassium in the faeces when steroids are given may lead to erroneous conclusions on the influence of steroids upon potassium metabolism (Bagshawe, Curtis, and Garnett, 1965; Ross, 1965).

Finally, it may very well be that the increased intestinal secretion of potassium ions, observed after operation (Shields, 1965b), can be ascribed to a posttraumatic increase in adrenal-cortical activity.

\section{SUMMARY}

The intestinal transport of potassium, sodium, and water was studied in isolated segments of ileum and colon of the dog and of the colon in man. When aldosterone was given as a continuous infusion, the net secretion of potassium by the intestine was enhanced by a marked increase in the rate at which potassium ions entered the intestinal lumen. The movements of sodium and of water were not affected. As a result, the concentration of potassium in the intestinal content was increased. A single injection of aldosterone had only a transient and slight effect upon potassium transport.

Aldosterone seems to influence the intestinal handling of electrolytes in a manner which, in several respects, resembles its effect upon the renal tubules. In states of increased adrenocortical activity, potassium losses into the intestinal lumen may be high, and go unrecognized clinically.

We should like to acknowledge our indebtedness to Professor Sir Charles Illingworth and Professor A. P. M. Forrest for their support, interest, and encouragement. We wish to thank Dr. G. I. Eglinton and Dr. J. H. Thomas of the Departments of Chemistry in the University of Glasgow and in the University College of South Wales and Monmouthshire, Cardiff, for allowing us to use their infra-red spectrophotometers. For their advice on radioactive matters and assistance with nucleonic equipment, we thank Drs. Michael Bluhm, James
Valentine, and Harold Glass of the Regional Physics Department, Glasgow, and Mr. Glynn M. Owen of the South Wales Radiotherapy Service.

The animal experiments were performed in the Wellcome Research Laboratories, to whose staff, under the direction of Professor W. L. Weipers, we are grateful for the care and attention given to the dogs. We thank Dr. A. K. Pitman of CIBA Laboratories for the gifts of aldosterone, and Mr. R. W. Larkin of the London Rubber Company for the miniature balloons.

The illustrations were prepared by the staff of Medical Illustration Department of the Cardiff Royal Infirmary under the direction of Mr. R. G. Marshall.

Part of this work was supported by a grant from the Medical Research Council.

\section{REFERENCES}

Ayers, C. R., Davis, J. O., Lieberman, F., Carpenter, C. C. J., and Berman, M. (1962). The effects of chronic hepatic venous congestion on the metabolism of $d, l$-aldosterone and $d$-aldosterone. J. clin. Invest., 41, 884-895.

Bagshawe, K. D., Curtis, J. R., and Garnett, E. S. (1965). Effect of prolonged hydrocortisone administration on potassium metabolism. Lancet, 1, 18-21.

Barger, A. C., Berlin, R. D., and Tulenko, J. F. (1958). Infusion of aldosterone, 9-x-fluorohydrocortisone and antidiuretic hormone into the renal artery of normal and adrenalectomized unanesthetized dogs: effect on electrolyte and water excretion. Endocrinology, 62, 804-815.

Bartter, F. C. (1960). The Clinical Use of Aldosterone Antagonists. Thomas, Springfield, Ill.

Berger, E. Y., Kanzaki, G., Homer, M. A., and Steele, J. M. (1959). Simultaneous flux of sodium into and out of the dog intestine. Amer. J. Physiol., 196, 74-82.

—_ _ - and Steele, J. M. (1960). The effect of deoxycorticosterone on the unidirectional transfers of sodium and potassium into and out of the dog intestine. J. Physiol. (Lond.)., 151, 352-362.

- and Steele, J. M. (1958). The calculation of transfer rates in two compartment systems not in dynamic equilibrium. J. gen. Physiol., 41, 1135-1152.

Berglund-Larsson, U. (1956). Determination of small amounts of deuterium oxide in water by infra-red spectroscopy. Acta chem. scand., 10, 701-702.

Bucher, G. R., Anderson, C. E., and Robinson, C. S. (1950). Chemical changes produced in isotonic solutions of sodium sulfate and sodium chloride by the small intestine of the dog. Amer. J. Physiol., 163, 1-13.

Clark, W. G. (1939). Effect of adrenalectomy upon intestinal absorption of sodium chloride. Proc. Soc. exp. Biol. (N.Y.), 40, 468470.

Clarke, A. M., and Shields, R. (1963). The role of the intestine in fluid and electrolyte conservation during sodium depletion. (Abstract.) Brit. J. Surg., 50, 768.

Code, C. F. (1960). The semantics of the process of absorption. Perspect. Biol. Med., 3, 560-562.

__, Bass, P., McClary, G. B., Jr., Newnum, R. L., and Orvis, A. L. (1960). Absorption of water, sodium and potassium in small intestine of dogs. Amer. J. Physiol., 199, 281-288.

- , and McIntire, F. C. (1956). Quantitative determination of histamine. Meth. biochem. Anal., 3, 49-95.

Conn, J. W. (1949). Electrolyte composition of sweat. Arch. intern. Med., 83, 416-428.

—, Louis, L. H., Johnston, M. W., and Johnson, B. J. (1948). The electrolyte content of thermal sweat as an index of adrenal cortical function. (Abstract.) J. clin. Invest., 27, 529-530.

Cooperstein, I. L., and Brockman, S. K. (1959). The electrical potential difference generated by the large intestine: its relation to electrolyte and water transfer. $J$. clin. Invest., 38, 435-442.

Curran, P. F., and Solomon, A. K. (1957). Ion and water fluxes in the ileum of rats. J. gen. Physiol., 41, 143-168.

Dennis, C. (1939). Oblique aseptic, end-to-end intestinal anastomosis. Surgery, 5, 548-553.

- , and Wood E. H. (1940). Intestinal absorption in the adrenalectomized dog. Amer. J. Physiol., 129, 182-190. 
Dingman, J. F., Finkenstaedt, J. T., Laidlaw, J. C., Renold, A. E., Jenkins, D., Merrill, J. P., and Thorn, G. W. (1958). Influence of intravenously administered adrenal steroids on sodium and water excretion in normal and Addisonian subjects . Metabolism, 7, 608-623.

Elmslie, R. G., Mulholland, A. T., and Shields, R. (1966). The blocking by spironolactone (S.C. 9420) of the action of aldosterone infusions upon the intestinal transport of potassium, sodium, and water. Gut, 7, 697-699.

Frawley, T. F., and Thorn, G. W. (1951). The relation of the salivary sodium-potassium ratio to adrenalcortical activity. In Proceedings of the 2nd Clinical ACTH Conference, edited by J. R.Mole, Vol. I, p.p. 115-122. Churchill, London.

Grim, E. (1962). Water and electrolyte flux rates in the duodenum, jejunum, ileum and colon, and effects of osmolarity. Amer. $J$. dig. Dis., 7, 17-27.

Grundy, H. M., Simpson, S. A., and Tait, J. F. (1952). Isolation of a highly active mineralcorticoid from beef adrenal extract. Nature (Lond.) 169, 795-796.

Kruhoffer, P., Thaysen, J. H., and Thorn, N. A. (1960). The alkali metal ions in the organism. In The Alkali Metal Ions in Biology, by H. H. Ussing, et al., pp. 196-598. (Handbuch der experimentellen Pharmakologie, Bd. 13, Erganzung.) Springer, Berlin.

Lipsett, M. B., Schwartz, I. L., and Thorn, N. A. (1961). Hormonal control of sodium, potassium, chloride and water metabolism. In Mineral Metabolism, by C. L. Comar and F. Bronner, Vol. 1 Part B, pp. 473-549. Academic Press, London and New York.

Miles, J. B., and Shields, R. (1966). The movement of water, sodium, and potassium into and out of the intact human colon in primary hyperaldosteronism. Submitted for publication.

Robinson, C. V., Arons, W. L., and Solomon, A. K. (1955). An improved method for simultaneous determination of exchangeable body sodium and potassium. J. clin. Invest., 34, 134-140.

Ross, E. J. (1965). Effect of prolonged hydrocortisone administration on potassium metabolism. Lancet, 1, 215.

_ Reddy, W. J., Rivera, A., and Thorn, G. W. (1959). Effects of intravenous infusions of $\mathrm{dl}$-aldosterone acetate on sodium and potassium excretion in man. J. clin. Endocr., 19, 289-296.

Schmidlin, J., Anner, G., Billeter, J.-R., and Wettstein, A. (1955). Uber Synthesen in der Aldosteron-Reihe I. Totalsynthese des racemischen Aldosterons. Experientia (Basel), 11, 365-368.

Shields, R. (1964). Surgical aspects of the absorption of water and electrolytes by the intestine. Monogr. surg. Sci., 1, 119-172.

- $(1965 a)$. A study of several factors affecting the intestinal absorption of water, sodium and potassium. M.D. Thesis. University of Glasgow.

- $(1965 b)$. The absorption and secretion of fluid and electrolytes by the obstructed bowel. Brit. J. Surg., 52, 774-779.

— and Elmslie, R. G. (1962). The effect of aldosterone on absorption of water and electrolytes from the ileum and colon of the dog. (Abstract.) Ibid., 50, 96-97.

Stein, L., and Wertheimer, E. (1941). Effect of adrenalectomy on intestinal absorption involving osmotic work in rats. Proc. Soc. exp. Biol. (N.Y.), 46, 172-174.

Tait, J. F., Simpson, S. A., and Grundy, H. M. (1952). The effect of adrenal extract on mineral metabolism. Lancet, 1, 122-124.

Veall, N., and Vetter, H. (1958). Radioisotope Techniques in Clinical Research and Diagnosis. Butterworth, London.

Visscher, M. B., Fetcher, E. S., Carr, C. W., Gregor, H. P., Bushey, M. S., and Barker, D. E. (1944a). Isoptic tracer studies on the movement of water and ions between intestinal lumen and blood. Amer. J. Physiol., 142, 550-575.

-, Varco, R. H., Carr, C. W., Dean, R. B., and Erickson, D. (1944b) Sodium ion movement between the intestinal lumen and the blood. Amer. J. Physiol., 141, 488-505.

Wright, R. D. (1962). Control of secretion of aldosterone. Brit. med. Bull., 18, 159-163.

\section{APPENDIX}

THE FORMULAE FOR THE CALCULATION OF THE RATES OF MOVEMENT OF WATER, SODIUM, AND POTASSIUM

A CALCUlation OF THE RATE OF NET MOVEMENT OF WATER ( $\left.\mathrm{H}_{2} \mathrm{O}_{\text {net }}\right)$

$$
\mathrm{H}_{2} \mathrm{O}_{\text {net }}=\mathrm{V}_{\mathrm{o}}-\mathrm{V}_{\mathrm{t}}
$$

where $V_{0}$ is the volume of solution instilled and $V_{t}$ the volume of solution unabsorbed after time $t$.

B CALCUlation OF THE RATE OF NET MOVEMENT OF ELECTROLYTE (e.g., $\left.\mathrm{Na}^{+}{ }_{\text {net}}\right)$

$\mathrm{Na}^{+}{ }_{\text {net }}=\left[\mathrm{Na}^{+}\right]_{0} \cdot \mathrm{V}_{\mathbf{o}}-\left[\mathrm{Na}^{+}\right]_{t} \cdot \mathrm{V}_{\mathrm{t}}$

where $\left[\mathrm{Na}^{+}\right]_{b}$ and $\left[\mathrm{Na}^{+}\right]_{t}$ are the chemical concentrations (in $\mathrm{mEq} . / \mathrm{L}$ ) of sodium ions (labelled and unlabelled) in the test solution instilled and withdrawn from the gut after time $t$.

C CALCULATION OF THE RATE OF INSORPTION OF ELECTROLYTES (e.g., $\mathrm{Na}^{+}{ }_{\text {ins }}$ )

The formula, given by Visscher et al. (1944b), was written by the authors as

$$
\mathrm{Na}^{+}{ }_{\text {ins }}=\frac{\left[\mathrm{Na}^{+}\right]_{\mathrm{o}} \cdot \mathrm{V}_{\mathrm{o}}-\left[\mathrm{Na}^{+}\right]_{\mathrm{o}} \cdot \mathrm{V}_{\mathrm{t}} \cdot \mathrm{A}_{\text {na.t }} / \mathrm{A}_{\text {na.o }}}{\frac{1}{2}\left\{1+\frac{\mathrm{A}_{\text {na.t. }}\left[\mathrm{Na}^{+}\right]_{\mathrm{o}}}{\mathrm{A}_{\text {na. o. }}\left[\mathrm{Na}^{+}\right]_{\mathrm{t}}}\right\}}
$$

where $A_{\text {na.o }}$ and $A_{\text {na.t }}$ are the counts per second per ml. due to radiosodium in the solutions, instilled and withdrawn respectively.

This formula may be simplified and made more meaningful by multiplying the numerator by $A_{\text {na.o }} / A_{\text {na.o }}$.

Thus $\left[\mathrm{Na}^{+}\right]_{0}, \mathrm{~V}_{\mathrm{o}} \cdot \mathrm{A}_{\text {na.o }}-\left[\mathrm{Na}^{+}\right]_{0} \cdot \mathrm{V}_{\mathrm{t}} . \mathrm{A}_{\text {na.t. }} \mathbf{A}_{\text {na.o }}$

$$
\begin{aligned}
& \text { Ana.o } \\
& \frac{1}{2}\left\{\frac{\left[\mathrm{Na}^{+}\right]_{0} \cdot A_{\text {na.o }}}{\left[\mathrm{Na}^{+}\right]_{\mathrm{o}} \cdot \mathrm{A}_{\text {na.o }}}+\frac{\left[\mathrm{Na}^{+}\right]_{\mathrm{o}} \cdot \mathrm{A}_{\text {na.t }}}{\left[\mathrm{Na}^{+}\right]_{\mathrm{t}} \cdot \mathrm{A}_{\text {na.o }}}\right\} \\
& =\frac{A_{\text {na.o. }} \cdot V_{0}-A_{\text {na.t }} \cdot V_{t}}{\frac{1}{2}\left(A_{\text {na.o } /}\left[\mathrm{Na}^{+}\right]_{0}+A_{\text {na. }}+\left[\mathrm{Na}^{+}\right]_{t}\right)} \\
& \text { Ana.o. Ana.o } \\
& \text { Quantity of isotope moved out of lumen } \\
& \text { Arithmetic mean of the specific activity of the } \\
& \text { luminal solution }
\end{aligned}
$$

The rate of insorption of potassium can be calculated from a corresponding formula.

D THE CALCULATION OF THE RATE OF INSORPTION OF WATER ( $\mathrm{H}_{2} \mathrm{O}_{\text {ins }}$ ) (VISSCHER et al., 1944A)

$$
\mathrm{H}_{2} \mathrm{O}_{\text {ins }}=\left(D_{0} \cdot V_{\mathrm{o}}-\mathrm{D}_{\mathrm{t}} \cdot \mathrm{V}_{\mathrm{t}}\right) / \frac{1}{2} \cdot\left(\mathrm{D}_{\mathrm{o}}-\mathrm{D}_{\mathrm{t}}\right)
$$

where $D_{0}$ and $D_{t}$ are the concentrations of $D_{2} O$ (in atoms per cent excess) in the test solution instilled and withdrawn after time $t$. 